\title{
Strategies to combat the deleterious impacts of heat stress through feed restrictions and dietary supplementation (vitamins, minerals) in broilers
}

\author{
A. S. A. Mohamed ${ }^{1,2, *}$, A. R. Lozovskiy ${ }^{1}$ and A.M.A. Ali ${ }^{\mathbf{3}}$ \\ ${ }^{1}$ Zootechny \& Agricultural Produce Processing Technology, \\ Faculty of Agribusiness, Technologies \& Veterinary Medicine, \\ Astrakhan State University, 414000 Astrakhan - Russia \\ ${ }^{2}$ Permanent address: Department of Animal and Poultry Production, Faculty of Agriculture, \\ Minia University, 61519 El-Menia - Egypt \\ ${ }^{3}$ Department of Botany and Microbiology, Faculty of Science, \\ Minia University, 61519 El-Menia - Egypt \\ *Corresponding E-mail : abdalhmed.salah@yahoo.com
}

Received November 11, 2018; Accepted March 21, 2019

\begin{abstract}
ABSTRAK
Tujuan penelitian ini adalah untuk mengevaluasi effect pembatasan pakan (FR) selama 3 jam dan/ atau suplementasi makanan dengan vitamin dan mineral terhadap pertumbuhan, tingkat mortalitas, beberapa sifat karkas, dan indeks biokimia serum dari anak ayam broiler di bawah tekanan panas di sistem kandang terbuka. Sebanyak 240 ayam pedaging berumur satu minggu ditimbang dan secara acak dikenai 4 jenis perlakuan eksperimental. Perlakuan 1 (T1): ayam diberi makan ad libitum pada diet basal, T2: ayam diberi pakan basal dengan FR, T3: ayam diberi makan ad libitum pada diet basal dengan vitamin C (200 mg) + vitamin E (200 mg) + Cr (1,5 mg) + Zn (100 mg) per kg pakan, dan T4: ayam diberi makan dengan diet basal dengan FR dan kombinasi suplemen vitamin dan mineral. Ditemukan bahwa parameter pertumbuhan meningkat pada T2, T3, dan T4, sementara tingkat kematian berkurang secara signifikan dibandingkan dengan kontrol. FR dan aditif pakan (T4) menunjukkan peningkatan total protein serum dan penurunan total kolesterol serum. Disimpulkan bahwa efek kombinasi FR dan aditif pakan dapat secara signifikan mengurangi efek stres panas untuk ayam pedaging dengan meningkatkan kinerja pertumbuhan dan menurunkan tingkat kematian.

Kata kunci: stres panas, aditif pakan, pembatasan pakan, pertumbuhan, mortalitas
\end{abstract}

\begin{abstract}
The objective of the current study was to evaluate the impacts of feed restriction (FR) for 3 hours and/or dietary supplementation with vitamins and minerals on growth, mortality rate, some carcass traits, and serum biochemistry indices of broiler chicks under heat stress in the open housing system. A total of 240 one-week old broilers were weighed and randomly assigned into 4 equal experimental treatments. Treatment 1 (T1) was fed ad libitum on basal diets, T2 birds were fed on basal diets with FR, T3 birds were fed ad libitum on basal diets with vitamin C (200 mg) + vitamin E (200 mg) + Cr (1.5 $\mathrm{mg})+\mathrm{Zn}(100 \mathrm{mg})$ per $\mathrm{kg}$ diet, and $\mathrm{T} 4$ birds were fed on basal diets with FR and combined supplementation of vitamins and minerals. It was found that growth parameters improved in T2, T3, and T4, while the mortality rate was significantly reduced compared with control. FR and feed additives (T4) revealed marked increases in serum total protein and a decrease in total serum cholesterol. It was
\end{abstract}


concluded that combined effect of FR and feed additives could significantly alleviate heat stress effects for broilers by improving growth performance and decreasing mortality rate.

Keywords: heat stress, feed additives, feed restriction, growth, mortality

\section{INTRODUCTION}

Heat stress (HS) indicates an imbalance between body heat loss and heat production that connects to air temperature, relative humidity $(\mathrm{RH})$, air speed, and radiant heat, which play the main roles in producing HS (Alagawany et al., 2017). Currently, climate changes and temperatures increases have been recorded in numerous regions (Smith and Gregory, 2013). This will lead to increasing ambient temperature regularly in subtropical and tropical regions. During the summer season in the South of Russia, the temperature reaches $36-42^{\circ} \mathrm{C}$ (Fisinin and Kavtarashvili., 2015), and in Egypt, the temperatures reach $40^{\circ} \mathrm{C}$ and the humidity reaches $75 \%$ (Tawfeek et al., 2014). Strains of broiler chicken are particularly sensitive to high environmental temperatures because of their feathers and lack of sweat glands on the skin. Furthermore, the reduction in heat tolerance of commercial broiler crosses results from the higher metabolism by intensive genetic selection for more rapid growth (Zhang et al., 2017).

As observed from previous studies, to overcome HS effects in broilers by nutritional strategies, one of the two main methods must be followed. Firstly, in feed restriction (FR), whether quantitative or qualitative, chicks have partial access to nutrients which are required for their optimal growth and development (Khetani et al., 2009). However, previous studies have shown that the effect of FR methods on broiler performance is variable because many factors (timing, strain, age, sex, etc.) affect the responses of broilers to FR (Novele et al., 2008). Various methods of FR have been used in stressed broilers can lead to a reduction in growth, and metabolic activity to some extent and reduce the occurrence of metabolic diseases which manage to an increase of feed efficiency in broilers (Mench., 2002). Secondly, feed additives like vitamins, minerals, and amino acids are used for alleviating HS impacts on broiler performance (Attia et al., 2017; Hamidi and Pourreza., 2009). In high temperatures, chicks spend a short time in feeding, additional time in drinking, resting and panting as well as extra time in elevating their wings (Mack et al., 2013). HS leads to feed intake depression, resulting in the intake of fewer nutrients for healthy growth and development of broilers. As a result, high temperatures stress might cause a redirection in minerals and vitamins flow to meet metabolic requirements for immune responses in broilers (Niu, 2009 and Amizar et al., 2017) as well as an increase in vitamins and minerals mobilization and excretion (Bartlett and Smith., 2003; Aengwanich., 2008).

Ascorbic acid can improve the immune system, which enhances resistance to infections (Khan et al. 2012). Supplemental vitamin C leads to an increase in growth parameters and immunity responses under various environmental stressors (Attia et al., 2011; Khan et al. 2012). Vitamin E is a lipid-soluble antioxidant that is considered to be protective of lipid component in biological membranes that can protect them from free radical damage in stressed broilers. Additionally, dietary supplementation with vitamin $\mathrm{E}$ has been proven to improve the growth performance and immunity in broilers (El Dein et al., 2013).

Trace minerals of $\mathrm{Cr}$ and $\mathrm{Zn}$ play a decisive role in broiler production through improvement in physiological and metabolic functions included enzyme secretion of the digestive system thereby increasing the digestion of nutrients and, consequently, growth performance (Sahin and Kucuk., 2003; Khan et al., 2012). It has been reported that $\mathrm{Cr}$ increased weight gain of chicks and improved feed conversion as a result of the improved digestibility of nutrients and metabolism. Besides, adding $\mathrm{Cr}$ to diets can increase relative organs in meat-type chickens (Khan et al., 2014; Sahin et al., 2018). Zn is one of the essential trace elements in broiler physiology which has been found to enhance feed intake and improve growth rate and immune system function (Naz et al., 2016).

Previous studies have evaluated the effect of FR and individual supplementation of vitamin $C$, vitamin $\mathrm{E}, \mathrm{Cr}$, and $\mathrm{Zn}$ in poultry production. However, there is still paucity of data on combined impact of the FR method and feed additives in broilers under heat stress. Therefore, this work aimed to investigate the influence of FR and/or vitamin $\mathrm{C}$, vitamin $\mathrm{E}$, mineral $\mathrm{Cr}$ and $\mathrm{Zn}$ supplementation on the performance of broilers under HS in open housing. This study was 
dependently designed based on the results of own previous experiments (Mohamed et al., 2019).

\section{MATERIALS AND METHODS}

\section{Birds and Management}

This study was conducted at Astrakhan State University (South Russia) during the summer months (July and August 2018). In an open housing system, 240 one-day-old, chicks (Ross 308) were purchased and kept in floor pens from day old to 35 days of age with initial body weight of $43.00 \pm 0.65 \mathrm{~g}$. Broilers were reared on a chopped mixture of wood shavings and wheat straw after the initial 7 days of brooding, while chicks were brooded together and fed a basal diet with feed and water ad libitum. An alighting period was 23 hours per day throughout the first week of brooding and throughout the experimental period (7-35 days). Chicks were weighed and grouped at random into 4 experimental groups consisting of three replicates. Chicks in each replicate (20 chicks) were allocated with floor space $2.5 \mathrm{~m}^{2}$ (calculated based on 8 chicks $/ \mathrm{m}^{2}$ ). Broiler chicks at all treatments were fed on commercial diets by starter and finisher according to National Research Council (NRC, 1994). The trial period was classified into two feeding periods: starter period from 1 to 21 days of age and finisher period from 22 to 35 days of age. Ingredients of diets of experiment and their nutrient composition are presented in Table 1. Nutrient composition was determined according to Association of Official Analytical Chemists (AOAC, 2005). The experimental treatments are detailed in Table 2.

The temperature of brooding (1-7 days) was 33 to $35{ }^{\circ} \mathrm{C}$ with relative humidity (RH) ranged from 58.4 to $65.5 \%$. The ambient temperatures and relative humidity \% were noted daily every 6 hours except for the period from 12:00 pm to 16:00 pm, when it was noted every hour. The temperature and humidity $\%$ throughout the experimental period (8-35 days of age) are detailed in Table 3.

\section{Growth Performance Parameters and Mortality}

Body weight (BW) and feed intake (FI) were recorded weekly, and total FI per week was divided by the number of chicks in each replicate to obtain the average weekly FI per bird. Body weight gain (BWG) was calculated weekly. And feed conversion ratio (FCR) was calculated weekly and fixed for a number of chicks per replicate and calculated on the basis of a kilogram $(\mathrm{kg})$ of FI per $1 \mathrm{~kg}$ of live BWG. Mortality rate was noticed daily.

\section{Carcass Traits}

At day 35 of age (the end of the trial period), after 12 hours of fasting, in each replicate, 9 chicks were randomly chosen in each treatment then weighted and slaughtered to determine broiler carcass traits. The feathers were picked, eviscerated carcass weights (g) without giblets and yield (\%) were calculated, and liver, abdominal fat, and spleen were removed, separately weighted, and presented in percentage forms of live BW (AOAC, 2005).

\section{Serum Biochemistry Indices}

During slaughtering (day 35), 9 blood samples per treatment were collected ( $3 /$ replicate) in clean centrifuge tubes for measurement of blood parameters. The samples were left for 20 minutes at room temperature to clot. Then, samples were centrifuged at $3,000 \mathrm{rpm}$ for 15 minutes to separate serum from blood. Serum samples stored at $-20^{\circ} \mathrm{C}$ for measurement of total protein, albumin, uric acid, creatinine, glucose, triglycerides, total cholesterol, high-density lipoprotein cholesterol (HDL cholesterol) and low-density lipoprotein cholesterol (LDL cholesterol). These parameters were determined colorimetrically using commercial kits (produced by Olvex Diagnosticum, Russia) according to the manufacturer's recommendations.

\section{Statistical Analysis}

The obtained results of the experiment are shown as mean \pm SE. The statistical analysis processing of data was performed by one-way analysis of variance (ANOVA), using the general linear model (GLM) procedure of SAS software (Statistical analysis system, version 9.1.3, 2003). Duncan's multiple range test was applied to detect the significance degrees among means. Probability values less than $0.05(\mathrm{P}<0.05)$ was considered significant.

\section{RESULTS}

\section{Growth Performance and Mortality}

Resticted feeding method (3 hours) and/or dietary supplementation with vitamin $\mathrm{C}(200 \mathrm{mg})$, vitamin $\mathrm{E}(200 \mathrm{mg}), \mathrm{Cr}(1.5 \mathrm{mg})$, and $\mathrm{Zn}(100$ 
Table 1. Ingredient and Nutrient Composition of the Control Diet

\begin{tabular}{lcc}
\hline \multicolumn{1}{c}{ Ingredient, \% } & Starter (1-21 days of age) & Finisher (22-35 days of age) \\
\hline Yellow corn & 53.90 & 56.35 \\
Soybean meal & 32.10 & 3.50 \\
Corn gluten meal & 5.80 & 30.87 \\
Sun flower oil & 4.20 & 5.55 \\
Dicalcium phosphate & 1.80 & 1.68 \\
Sodium chloride & 0.30 & 0.30 \\
Limestone & 1.30 & 1.20 \\
DL-methionine & 0.15 & 0.10 \\
Lysine & 0.15 & 0.15 \\
Vitamin-mineral premix* & 0.30 & 0.30 \\
Analyzed chemical composition & & \\
Dry matter & 92.23 & 92.01 \\
Crude protein & 22.82 & 20.76 \\
Crude fiber & 3.05 & 3.22 \\
Ether extract & 6.45 & 7.92 \\
Calculated chemical composition & & \\
Metabolizable energy (MJ/kg) & 12.98 & 13.40 \\
Calcium & 0.99 & 0.93 \\
Available phosphorus & 0.47 & 0.45 \\
Methionine+ Cystine & 0.90 & 0.79 \\
\hline
\end{tabular}

*Provided per kilogram of diet: vitamin A, 12,500 IU; vitamin D3, $4000 \mathrm{IU}$; vitamin E, $30 \mathrm{IU}$; vitamin $\mathrm{K}, 2.3$ $\mathrm{mg}$; thiamine, $2.2 \mathrm{mg}$; riboflavin, $8 \mathrm{mg}$; pantothenic acid, $24.3 \mathrm{mg}$; niacin, $65 \mathrm{mg}$; pyridoxine, $4 \mathrm{mg}$; folic acid, $1.2 \mathrm{mg}$; biotin, $0.25 \mathrm{mg}$; vitamin B12, $3 \mathrm{mg}$; choline, $600 \mathrm{mg}$; iron from ferrous sulfate, $60 \mathrm{mg}$; copper from copper sulfate, $7.5 \mathrm{mg}$; manganese from manganese oxide, $125.1 \mathrm{mg}$; zinc from zinc oxide, $110 \mathrm{mg}$; iodine from ethylene diamine dihydroidide, $1.8 \mathrm{mg}$; selenium from sodium selenite, 0.35 .

$\mathrm{mg} /$ per $1 \mathrm{~kg}$ diet for broilers, in broilers improved growth performance parameters and decreased mortality rate in heat-stressed broiler chicks compared with the control treatment (Table 4). During all experimental periods, BW and BWG were higher in restricted broilers, ad libitum broilers with dietary supplementation of vitamin $\mathrm{C}$, vitamin $\mathrm{E}, \mathrm{Cr}, \mathrm{Zn}$, and their combination than those in the control treatment broilers.

No statistical difference in FI among treatments during the first two weeks (7-21) of the experimental period was detected. However, in the period from 22 to 35 days of age and throughout the 35-day period, FI was significantly decreased by applying FR method (T2) and dietary supplementation with vitamins and minerals (T3) separated or combined (T4) as compared to control (T1). There were statistical differences in FCR between experimental treatments (T2, T3, and T4) and the control in all trial periods. As compared with broilers in the control, the T2, T3, and T4 groups had lower FCR $13.30,14.78$, and $18.72 \%$, respectively than those fed the basal diet (T1) during the total period (735). The combined effect of FR and supplementation with vitamins + minerals exhibited the best FCR compared to the control and other treatments.

As shown in Table 4, mortality rate raised in the last two weeks of the trial period (22-35) in all treatments under HS, while the control (T1) showed the highest level (16.67\%) compared to 
Table 2. The Experimental Design

\begin{tabular}{|c|c|c|c|c|c|}
\hline \multirow[b]{2}{*}{ Treatments } & \multirow{2}{*}{$\begin{array}{c}\begin{array}{c}\text { Feed Restriction } \\
\text { (FR) }\end{array} \\
\text { Three hours } \\
\text { without feeding } \\
(12: 00-15: 00 \mathrm{pm})\end{array}$} & \multicolumn{2}{|c|}{ Vitamins, $\mathrm{mg} / \mathrm{kg}$ diet } & \multicolumn{2}{|c|}{ Minerals, $\mathrm{mg} / \mathrm{kg}$ diet } \\
\hline & & $\begin{array}{l}\text { Vitamin C (L- } \\
\text { ascorbic acid, } \\
99 \%)\end{array}$ & $\begin{array}{c}\text { Vitamin E (DL- } \alpha- \\
\text { Tocopherol } \\
\text { acetate, } 50- \\
52.6 \%)\end{array}$ & $\begin{array}{c}\mathrm{Cr} \text { (chromium } \\
\text { picolinate, } \\
\text { CrPic, } 12,42 \%)\end{array}$ & $\begin{array}{c}\mathrm{Zn} \\
(\mathrm{ZnSO} 4)\end{array}$ \\
\hline $\begin{array}{c}\mathrm{T} 1 \\
\text { (control) }\end{array}$ & - & - & - & - & - \\
\hline $\mathrm{T} 2$ & $\sqrt{ }$ & - & - & - & - \\
\hline $\mathrm{T} 3$ & - & 200 & 200 & 1.5 & 100 \\
\hline $\mathrm{T} 4$ & $\sqrt{ }$ & 200 & 200 & 1.5 & 100 \\
\hline
\end{tabular}

Table 3. Ambient Temperature and Relative Humidity during the Experimental Period (8-35 Days of Age) in Summer Season

\begin{tabular}{lcccc}
\hline \multirow{2}{*}{ Parameter } & \multicolumn{4}{c}{ Period (days) } \\
\cline { 2 - 5 } & $8-14$ & $15-21$ & $22-28$ & $28-35$ \\
\hline Ambient temperature, ${ }^{\circ} \mathrm{C}$ & 32.20 & 31.30 & 31.50 & 31.30 \\
Ambient temperature (12:00-16:00 pm), ${ }^{\circ} \mathrm{C}$ & 32.90 & 32.60 & 32.70 & 32.30 \\
Relative Humidity (RH), $\%$ & 71.7 & 76.21 & 68.5 & 78.9 \\
\hline
\end{tabular}

T2, T3, and T4 (16.67, 8.33, 6.67, and 5.00\%, respectively) during the whole period (days 7-35).

\section{Carcass Traits}

The results of quantitative FR (3 hours) and/or dietary supplementation (vitamins and minerals) on carcass yield, liver, spleen and abdominal fat are presented in Table 5. The FR strategy and/or adding feed additives (vitamin $\mathrm{C}$, vitamin $\mathrm{E}, \mathrm{Cr}, \mathrm{Zn}$ ) improved carcass, spleen yields, and reduced abdominal fat but there was no effect on liver weight. The high values of carcass and spleen yields were noticed for broiler chicks in T4 compared to other treatments and the control. Moreover, abdominal fat deposition in $\mathrm{T} 2$, T3 and T4 decreased by $15.43 \%, 21.81 \%$, and $32.98 \%$, respectively, compared with broilers in the control at high environmental temperatures.

\section{Serum Biochemistry Indices}

The impacts of FR and/or dietary supplementation under HS on serum concentrations of total protein, albumin, creatinine, uric acid, glucose, triglycerides, total cholesterol, HDL cholesterol, and LDL cholesterol are presented in Table 6. Feed restricted broilers (T2) had no significant difference in serum total protein, but in $\mathrm{T} 3$ and $\mathrm{T} 4$ significantly increased by $11.48 \%$ and $16.61 \%$, respectively, as compared to the control group (T1). Serum creatinine, uric acid, and glucose were lower in T2, T3, and T4 than in the control group (T1). At high temperatures, FR and/or dietary supplementation (T2, T3, and T4) significantly decreased the serum of total lipids and LDL cholesterol in comparison with the control (T1). Moreover, the combination of FR (3 hours) and dietary supplementation with vitamin $\mathrm{C}(200 \mathrm{mg})$, vitamin E (200 mg), Cr (1.5 mg), and $\mathrm{Zn}(100 \mathrm{mg})$ per $\mathrm{kg}$ diet, had the highest levels in serum of total protein, albumin, and HDL cholesterol and the lowest levels in serum 
Table 4. Growth Performance and Mortality Rate of Broilers as Affected by Feed Restriction (FR), Dietary Supplementation with Vitamins (C, E) and Minerals (Cr, Zn) under Heat Stress

\begin{tabular}{|c|c|c|c|c|c|c|}
\hline \multirow{2}{*}{ Parameter } & \multicolumn{4}{|c|}{ Treatments* } & \multirow{2}{*}{ SEM } & \multirow{2}{*}{ p-value } \\
\hline & $\mathrm{T} 1$ (control) & $\mathrm{T} 2$ & $\mathrm{~T} 3$ & $\mathrm{~T} 4$ & & \\
\hline \multicolumn{7}{|c|}{ Body weight (BW), g } \\
\hline 7 day & 155.43 & 149.82 & 155.87 & 155.70 & 2.75 & 0.39 \\
\hline 21day & $754.90^{\mathrm{c}}$ & $775.32^{\mathrm{bc}}$ & $787.87^{\mathrm{ab}}$ & $806.46^{\mathrm{a}}$ & 6.45 & 0.003 \\
\hline 35 day & $1665.36^{\mathrm{c}}$ & $1792.38^{\mathrm{b}}$ & $1815.38^{\mathrm{b}}$ & $1874.02^{\mathrm{a}}$ & 7.78 & 0.0001 \\
\hline \multicolumn{7}{|c|}{ Body weight gain (BWG), g } \\
\hline $7-21$ days & $599.48^{\mathrm{c}}$ & $625.51^{\mathrm{b}}$ & $632.00^{\mathrm{b}}$ & $650.75^{\mathrm{a}}$ & 4.92 & 0.001 \\
\hline 22-35 days & $910.46^{\mathrm{c}}$ & $1017.05^{\mathrm{b}}$ & $1027.51^{b}$ & $1067.57^{\mathrm{a}}$ & 7.52 & 0.0001 \\
\hline 7-35 days & $1509.93^{\mathrm{c}}$ & $1642.56^{\mathrm{b}}$ & $1659.51^{b}$ & $1718.32^{\mathrm{a}}$ & 7.25 & 0.0001 \\
\hline \multicolumn{7}{|c|}{ Feed intake (FI), g } \\
\hline 7-21days & 986.00 & 946.96 & 935.78 & 933.73 & 15.03 & 0.12 \\
\hline 22-35days & $2074.32^{\mathrm{a}}$ & $1950.01^{b}$ & $1933.06^{\mathrm{b}}$ & $1900.18^{\mathrm{b}}$ & 15.94 & 0.0003 \\
\hline 7-35 days & $3060.33^{\mathrm{a}}$ & $2896.97^{b}$ & $2868.85^{\mathrm{bc}}$ & $2833.91^{\mathrm{c}}$ & 12.41 & 0.0001 \\
\hline \multicolumn{7}{|c|}{ Feed conversion ratio (FCR) } \\
\hline 7-21 days & $1.65^{\mathrm{a}}$ & $1.51^{\mathrm{b}}$ & $1.48^{\mathrm{bc}}$ & $1.43^{\mathrm{c}}$ & 0.02 & 0.001 \\
\hline 22-35 days & $2.28^{\mathrm{a}}$ & $1.92^{\mathrm{b}}$ & $1.88^{\mathrm{b}}$ & $1.78^{\mathrm{c}}$ & 0.02 & 0.0001 \\
\hline 7-35 days & $2.03^{\mathrm{a}}$ & $1.76^{\mathrm{b}}$ & $1.73^{\mathrm{b}}$ & $1.65^{\mathrm{c}}$ & 0.01 & 0.0001 \\
\hline \multicolumn{7}{|l|}{ Mortality rate } \\
\hline $7-21$ days & 6.67 & 1.67 & 0.00 & 0.00 & & \\
\hline 22-35 days & 10.62 & 6.75 & 6.67 & 5 & & \\
\hline $7-35$ days & 16.67 & 8.33 & 6.67 & 5 & & \\
\hline
\end{tabular}

* See Table 2. ${ }^{a, b, c}$ - means with different letters in the same row are significantly different at $(\mathrm{P}<0.05)$. SEM, standard error of the mean. BW and FI were measured weekly but the results of 7,21 and 35 are presented in the table.

glucose, triglycerides, total cholesterol, and LDL cholesterol compared with T1, T2, and T3.

\section{DISCUSSION}

Our previous work (Mohamed et al., 2019), we aimed to determine the best levels of FR (in timing) and feed additives (quantities). Thus, this study investigated to the combination of FR (3 hours) and feed additives (200 $\mathrm{mg}$ of vitamin C; $200 \mathrm{mg}$ of vitamin $\mathrm{E} ; 1.5 \mathrm{mg}$ of $\mathrm{Cr}$; $100 \mathrm{mg}$ of
$\mathrm{Zn} \mathrm{/} \mathrm{kg}$ diet) to improve the productivity of broilers and decrease mortality rate under summer conditions (HS) in open housing. There is the question of whether combining both FR and dietary supplementation (vitamin $\mathrm{C}$, vitamin $\mathrm{E}$, $\mathrm{Cr}, \mathrm{Zn}$ ) can further alleviate the harmful effects of HS in broiler chicks. To our information, there is no data about experiments designed to study the impact of combining both procedures on the productivity in broilers under summer conditions. 
Table 5. Carcass Traits of Broilers as Affected by Feed Restriction (FR) and Dietary Supplementation with Vitamins (C, E) and Minerals (Cr, Zn) under Heat Stress

\begin{tabular}{|c|c|c|c|c|c|c|}
\hline \multirow{2}{*}{ Parameter } & \multicolumn{4}{|c|}{ Treatment* } & \multirow[b]{2}{*}{ SEM } & \multirow[b]{2}{*}{ p-value } \\
\hline & T1 (control) & $\mathrm{T} 2$ & T3 & $\mathrm{T} 4$ & & \\
\hline Carcass yield (\%) & $70.34^{\mathrm{d}}$ & $71.45^{\mathrm{c}}$ & $72.05^{\mathrm{b}}$ & $72.82^{\mathrm{a}}$ & 0.09 & 0.0001 \\
\hline Liver $(\%)$ & 2.42 & 2.48 & 2.47 & 2.51 & 0.06 & 0.78 \\
\hline Spleen $(\%)$ & $0.10^{\mathrm{c}}$ & $0.13^{\mathrm{b}}$ & $0.15^{\mathrm{ab}}$ & $0.18^{\mathrm{a}}$ & 0.01 & 0.001 \\
\hline Abdominal fat yield (\%) & $1.88^{\mathrm{a}}$ & $1.59^{\mathrm{b}}$ & $1.47^{\mathrm{b}}$ & $1.26^{\mathrm{c}}$ & 0.06 & 0.001 \\
\hline
\end{tabular}

* See Table 2. ${ }^{a, b, c, d}$ - means with different letters in the same row are significantly different at $(\mathrm{P}<0.05)$.

Table 6. Blood Parameters as Affected by Feed Restriction (FR) and Dietary Supplementation with Vitamins $(\mathrm{C}, \mathrm{E})$ and Minerals $(\mathrm{Cr}, \mathrm{Zn})$ under Heat Stress

\begin{tabular}{|c|c|c|c|c|c|c|}
\hline \multirow{2}{*}{ Parameter } & \multicolumn{4}{|c|}{ Treatment* } & \multirow[b]{2}{*}{ SEM } & \multirow[b]{2}{*}{ p-value } \\
\hline & $\mathrm{T} 1$ (control) & $\mathrm{T} 2$ & $\mathrm{~T} 3$ & $\mathrm{~T} 4$ & & \\
\hline Total protein $(\mathrm{g} / \mathrm{L})$ & $42.33^{\mathrm{c}}$ & $44.43^{\mathrm{c}}$ & $47.16^{\mathrm{b}}$ & $49.36^{\mathrm{a}}$ & 0.35 & 0.0001 \\
\hline Albumin $(\mathrm{g} / \mathrm{L})$ & $25.17^{\mathrm{d}}$ & $27.04^{\mathrm{c}}$ & $29.97^{b}$ & $30.92^{\mathrm{a}}$ & 0.18 & 0.0001 \\
\hline Creatinine $(\mu \mathrm{mol} / \mathrm{L})$ & $46.10^{\mathrm{d}}$ & $39.86^{\mathrm{c}}$ & $34.88^{\mathrm{b}}$ & $31.79^{\mathrm{a}}$ & 0.73 & 0.0001 \\
\hline Uric acid $(\mu \mathrm{mol} / \mathrm{L})$ & $490.67^{c}$ & $394.33^{\mathrm{cb}}$ & $355.67^{b}$ & $313.67^{\mathrm{a}}$ & 13.36 & 0.0001 \\
\hline Glucose (mmol/L) & $9.83^{\mathrm{a}}$ & $8.97^{\mathrm{b}}$ & $7.24^{\mathrm{c}}$ & $6.92^{\mathrm{c}}$ & 0.17 & 0.0001 \\
\hline Triglycerides (mmol/L) & $1.31^{\mathrm{a}}$ & $1.22^{\mathrm{a}}$ & $0.96^{\mathrm{b}}$ & $0.79^{\mathrm{c}}$ & 0.04 & 0.0001 \\
\hline Total cholesterol $(\mathrm{mmol} / \mathrm{L})$ & $3.31^{\mathrm{a}}$ & $3.03^{\mathrm{b}}$ & $2.89^{\mathrm{b}}$ & $2.59^{\mathrm{c}}$ & 0.06 & 0.0003 \\
\hline HDL cholesterol $(\mathrm{mmol} / \mathrm{L})$ & $0.99^{\mathrm{b}}$ & $1.13^{\mathrm{a}}$ & $1.20^{\mathrm{a}}$ & $1.20^{\mathrm{a}}$ & 0.04 & 0.02 \\
\hline LDL cholesterol (mmol/L) & $2.05^{\mathrm{a}}$ & $1.66^{\mathrm{b}}$ & $1.49^{\mathrm{b}}$ & $1.23^{\mathrm{c}}$ & 0.08 & 0.001 \\
\hline
\end{tabular}

* See Table 2. ${ }^{a, b, c, d}$ - means with different letters in the same row are significantly different at $(\mathrm{P}<0.05)$. SEM, standard error of the mean.

\section{Growth Performance and Mortality}

Restrictive feeding in broilers during the entire experimental period (7-35 days) in an opensided environment improved broiler performance by increasing $\mathrm{BW}(7,63 \%)$ and $\mathrm{BWG}(8.78 \%)$ and decreasing FI, FCR, and mortality rate (5.34, 13.30 , and $50.03 \%$, respectively) during the summer season. This agreed with the findings of previous studies (Novele et al., 2008; Butzen et al., 2013; Ozkan et al., 2010). The significant effect of FR in broilers may be associated with an increase in FI and the hypertrophy of the digestive tract that follows the FR period (Rincon and
Lesson., 2002). A reduction in body temperature of broilers as a result of a decline in FI leads to an increase in its survival ability (Basilio et al., 2001). Moreover, applying the FR method in broilers can improve their thermal resistance (Lin et al., 2006).

In the current study, a combined effect of vitamin $\mathrm{C}$, vitamin $\mathrm{E}, \mathrm{Cr}$, and $\mathrm{Zn}$ improved growth performance under summer conditions. BWG significantly increased (13.80\%), FCR improved (14.78\%), and mortality decreased $(59.99 \%)$. These results are in accordance with those presented by Tawfeek et al. (2014), who 
detected that dietary supplementation with vitamin $\mathrm{C}+$ vitamin $\mathrm{E}, \mathrm{Zn}+$ selenium, and $\mathrm{Cr}$ enhanced broiler performance under HS. Sahin et al. (2018) observed that supplemental $\mathrm{Cr}$ in hens overcomes the negative effects of HS on growth performance and metabolic profile. The combination of vitamin $\mathrm{C}$ and vitamin $\mathrm{E}$ in broiler diets markedly increased BWG and decreased FCR (Attia et al., 2017). Ali et al. (2018) showed that dietary supplementation with vitamin $\mathrm{E}, \mathrm{Cr}$, and $\mathrm{Zn}$ either individually or in combination enhanced BWG and FCR in broilers. The harmful effects of HS in broiler chicks are a result of a decrease in FI, increase in body temperature, depressed immune response, declined energy bioavailability in cells, digestibility of nutrients, metabolism, and absorption, damage in endocrine functions, disorders in the role and structure of intestinal epithelium, and variations in microbiota of the gut (Lara and Rostagno., 2013; Zhang et al., 2017; Wang et al., 2018). Dietary supplementation with feed additives (vitamins and minerals) may improve broiler performance and combat these deleterious effects (Sahin et al., 2018; Haq et al., 2018; Zhu et al., 2017; Attia et al., 2017). In this study, the beneficial impacts of feed additives on broiler growth may be due to the individual effects of vitamin $\mathrm{C}$, vitamin $\mathrm{E}, \mathrm{Cr}, \mathrm{Zn}$ or a combination. In contrast, previous studies have reported no significant effect on growth performance by supplementation with vitamin $\mathrm{C}$ (Abioja et al., 2011), vitamin E (Pompeu et al., 2016), Cr (Debski et al., 2004), and Zn (Hamidi and Pourreza., 2009).

The combination of FR and feed additives (T4) reached the highest levels while improving growth performance and decreasing mortality rate when compared with other treatments and control. At the end of the experiment ( 35 days), the BW of restricted broilers supplemented with vitamin $C$, vitamin $\mathrm{E}, \mathrm{Cr}$, and $\mathrm{Zn}$ was increased to $1,874 \mathrm{~g}$ versus $1,665,1,792$, and $1,815 \mathrm{~g}$ in $\mathrm{T} 1, \mathrm{~T} 2$, and $\mathrm{T} 3$, respectively. The combined effect in T4 represented a decrease in FI of approximately $7.40,2.18$, and $1.22 \%$ as compared with the control, T2, and T3, respectively. Moreover, FR with dietary supplementation recorded the lowest value in mortality rate by $5 \%$ as compared to $16.67,8.33$, and $6.67 \%$ in $\mathrm{T} 1, \mathrm{~T} 2$, and $\mathrm{T} 3$, respectively. The noted improvement in growth and mortality rate may be due to synergism between FR and feed additives, while each procedure has many positive effects on performance and mortality rate as previously explained. Our results are in agreement with those of Abdel-Hafeez et al. (2017), who reported that the biological feed additives with FR improved broiler performance.

\section{Carcass traits}

Results of the experiment confirmed that FR in broilers markedly enhanced carcass traits under summer conditions. However, liver yield was not significantly influenced. The significant effect of FR on carcass quality appeared in decreasing abdominal fat yield by $15.42 \%$ compared to the control (T1). This result is in agreements with those of Chen et al. (2012) who reported that there was no significant difference in liver weight between broilers in the control and FR broilers, while FR showed significantly increased spleen weight. In contrast, Shabani et al. (2015) indicated that FR was insufficient to improve carcass traits of broilers. As a result of FR, a decline in a fat deposition of FR broilers was mainly initiated by a reduction in feed fat (Chen et al., 2012). A decrease of abdominal fat (\%) by FR may contribute to the fasting period by more mobilization for energy and abdominal fat (Zhan et al., 2007; Nielsen et al., 2003). In this way, FR in broilers reared in summer conditions (HS) may be sufficient due to decreasing the activity of lipoprotein lipase enzymes in the chicken's adipose tissue. Lipoprotein lipase enzymes may control the release of fatty acids from lipoproteins and incorporation in adipocytes so that FR can reduce abdominal fat deposition (Faria et al., 2005; Ghazanfari, et al., 2010).

Dietary supplementation in stressed broilers markedly improved carcass and spleen yield and reduced abdominal fat. Similarly, Attia et al. (2017) found that supplementation of vitamin C and/or vitamin E slightly improved dressing percentage under heat stress. Khan et al. (2014) found that adding $\mathrm{Cr}$ to broiler diets increased lymphoid organ weight (spleen). The combined effects of $\mathrm{Cr}$ and vitamin $\mathrm{C}$ in broiler diets under HS improved quality and carcass traits (Haq et al., 2016). Broilers fed supplemental Cr 500, 1000, and $1500 \mathrm{ppb}$ under summer conditions showed significantly improved carcass yield and reduced abdominal fat (Toghyani et al., 2006). In this way, Al-Masad. (2012) indicated that the relative weight of the spleen increased by the combination effect of vitamin $\mathrm{C}$ and $\mathrm{Zn}$. The mechanism of additives in enhancing carcass traits might be due to protecting cells from the damaging effects of HS (Al-Masad., 2012). In addition, the 
improvement of carcass traits can contribute to enhanced growth performance.

FR with additives significantly increased carcass and spleen yields and decreased abdominal fat compared with control (T1) and other treatments in summer conditions. However, the combined effect did not affect liver yield. These results match the observations of AbdelHafeez et al. (2017), revealing that the biological supplementation of feed additives could be more effective, especially when FR method is followed. In general, these results may be due to the actual effect of feed additives and FR, which can improve the rate of metabolism and increase carcass characteristics.

\section{Serum biochemistry indices}

The blood components are sensitive to FR under high temperatures (HS). There was a notable increase in the albumin and HDL cholesterol, but a significant decline in glucose, creatinine, triglycerides, total cholesterol, and LDL cholesterol in serum stressed broilers in T2 compared with broilers in the control group. Nevertheless, total protein and uric acid were not significantly influenced. The results of this study are in line with those of Boostani et al. (2010), who reported that FR did not change the values of serum total protein but decreased glucose and serum cholesterol. Furthermore, FR did not affect total serum protein, but decreased serum total cholesterol and glucose (Abdel-Hafeez et al., 2017). On the other hand, Chen et al. (2012) revealed that serum glucose and triacylglycerols were not overtly influenced, but serum albumin, uric acid increased and total cholesterol, HDL cholesterol, LDL cholesterol were decreased by FR. In the present study, the significant differences in total lipids, triglycerides, HDL cholesterol, and LDL cholesterol may contribute to FR effects on lipid metabolism of broiler chicks through the changes in mitochondria function and morphology (Yang et al., 2010).

The combined effects of vitamin $\mathrm{C}$, vitamin $\mathrm{E}, \mathrm{Cr}$, and $\mathrm{Zn}$ markedly increased serum total protein, albumin, and HDL cholesterol but significantly reduced serum glucose, triglycerides, total cholesterol, LDL cholesterol, creatinine, and uric acid. These findings, except for glucose concentration, are similar to those of Tawfeek et al. (2014), who indicated that supplementation with vitamin $\mathrm{C}$, vitamin $\mathrm{E}, \mathrm{Zn}+$ selenium, and $\mathrm{Cr}$ recorded high values in total protein and low values in total cholesterol. Hag et al. (2018) showed that $\mathrm{Cr}(0.5 \mathrm{mg} / \mathrm{kg})$ with ascorbic acid $(250 \mathrm{mg} / \mathrm{kg})$ or $\mathrm{Cr}(0.5 \mathrm{mg} / \mathrm{kg})$ with vitamin $\mathrm{E}$ $(250 \mathrm{mg} / \mathrm{kg})$ reduced total lipids, triglycerides, LDL cholesterol, and glucose; however, HDL cholesterol was not statically influenced. Under HS effects $\left(35^{\circ} \mathrm{C}\right)$, dietary supplementation with $\mathrm{Zn}$ and vitamin $\mathrm{E}(50$ and $100 \mathrm{mg} / \mathrm{kg}$ diet, respectively) significantly lowered cholesterol, triglycerides, and glucose (Hosseini-Mansoub et al., 2010). Improvement of serum total protein in the present study can be explained via the increased time of digestibility in the digestive tract by slower passage time of feed as a result of a fundamental role of $\mathrm{Zn}$ that actives digestive enzymes, metabolism, and growth and promotes protein synthesis (Zakaria et al., 2017). The combined effect of FR with supplemental vitamins and minerals significantly improved total serum protein and decreased total cholesterol, uric acid, and creatinine as compared with control and other treatments (FR and feed additives for each study individually). In this study, the improvement of growth performance and a reduction in abdominal fat might reflect the high values of total protein and low values of total cholesterol and glycerides under HS by the combined effect of FR and feed additives. Furthermore, the significant improvement of growth and serum total protein in broilers (T4) leads to a decrease in protein catabolism in broilers (T4) as compared with broilers in control treatment under HS, which explained the increase in serum uric acid content in control compared with T4 (Xue et al., 2017).

\section{CONCLUSION}

Feed restriction for 3 hours in hot times and dietary supplementation with $200 \mathrm{mg}$ of vitamin C, $200 \mathrm{mg}$ of vitamin E, $1.5 \mathrm{mg}$ of $\mathrm{Cr}$, and 100 $\mathrm{mg}$ of $\mathrm{Zn}$ per $\mathrm{kg}$ diet improved growth and carcass characteristics and decreased mortality rate in heat stressed broilers. The combination of FR and feed additives was more effective $(\mathrm{P}<0.05)$ than the individual effect of each of them under summer conditions.

\section{ACKNOWLEDGMENTS}

This research was funded by Astrakhan State University in Russia and Minia University in Egypt (No. EGY-05-12023, 2016-2019). The author wishes to thank Prof. Dr. Shaker A. Abd EL-Latif, Minia University for valuable support 
and advice.

\section{REFERENCES}

Abdel-Hafeez, H.M., S.E.S. Elham, S.T. Samar, M.I.Y. Ibrahim and S.A.A. Asmaa. 2017. Effects of probiotic, prebiotic, and synbiotic with and without feed restriction on performance, hematological indices and carcass characteristics of broiler chickens. Asian-Australas. J. Anim. Sci. 30(5):672682.

Abioja, M.O., O.A. Osinowo, O.F. Smith, D. Eruvbetine and J.A. Abiona. 2011. Evaluation of cold water and vitamin $\mathrm{c}$ on broiler growth during hot-dry season in SW Nigeria. Arch. Zootec. 60(232): 1095-1103.

Aengwanich, W. 2008. Pathological changes and the effects of ascorbic acid on lesion scores of bursa of Fabricius in broilers under chronic heat stress. Res. J. Vet. Sci. 1:62-66.

Alagawany, M., M.R. Farag, M.E. Abd El-Hack and A. Patra. 2017. Heat stress effects on productive and reproductive performance of quail. World's Poult. Sci. J. 73(4):747-755.

Ali, N., M. Akram, A. Fahim, B. Singh and M. Imran. 2018. Effect of dietary supplementation of vitamin E, zinc and chromium supplementation on growth performance and hematological characteristics of broiler chickens. Indian J. Anim. Res. 52(4):574-578.

Al-Masad, M. 2012. Effects of vitamin C and zinc on broilers performance of immunocompetence under heat stress. Asian. J. Anim. Sci. 6(2):76-84

Amizar, R., S. Suharti, Jakaria and R. Mutia. 2017. The expression of heat shock protein 70 gene with organic selenium supplementation and its effect on productivity of broilers in tropical environment. J. Indonesian Trop. Anim. Agric. 42(4):279-287.

AOAC (Association of Official Analytical Chemists). 2005. Official methods of analysis of AOAC International, 18th ed. Gaithersburg, MD: AOAC International.

Attia, Y.A., A.A. Mohammed, S. E. Ali, Y.A. Rehab and W.K. Kim. 2017. Enhancing tolerance of broiler chickens to heat stress by supplementation with vitamin E, vitamin $\mathrm{C}$ and/or probiotics. Ann. Anim. Sci. 17(4): 1155-1169

Attia, Y.A., R. A. Hassan, A.E. Tag El-Din and
B.M. Abou-Shehema. 2011. Effect of ascorbic acid or increasing metabolizable energy level with or without supplementation of some essential amino acids on productive and physiological traits of slow-growing chicks exposed to chronic heat stress. J. Anim. Physiol. Anim. Nutr., 95(6):744-755.

Bartlett, J.R. and M.O. Smith, 2003. Effects of different levels of zinc on the performance and immunocompetence of broilers under heat stress. Poult. Sci. 82(10):1580-1588

Basilio, V.D.E., M. Vilarino, S. Yahav and M. Picard. 2001. Early age thermal conditioning and a dual feeding program for male broilers challenged by heat stress. Poult. Sci. 80(1): 29-36.

Boostani. A., A. Ashayerizadeh, M.H.R. Fard and A. Kamalzadeh. 2010. Comparison of the effects of several feed restriction periods to control ascites on performance, carcass characteristics and hematological indices of broiler chickens. Brazilian J. Poult. Sci. 12(3):171-177.

Butzen, F.M., A.M.L. Ribeiro, M.M. Vieira, A.M. Kessler, J.C. Dadalt and M. P. 2013. Early feed restriction in broilers. I-Performance, body fraction weights, and meat quality. J. Appl. Poult. Res. 22(2):251-259.

Chen, W., Y.M. Guo, Y.Q. Huang, Y.H. Shi, C.X. Zhang and J.W. Wang. 2012. Effect of energy restriction on growth, slaughter performance, serum biochemical parameters and Lpin2/WDTC1 mRNA expression of broilers in the later phase. J. Poult. Sci. 49(1):12-19.

Debski, B., W. Zalewskia, M.A. Gralaka and T. Kosla. 2004. Chromium-yeast supplementation of chicken broilers in an industrial farming system. J. Trace Elem. Med. Bio. 18(1):47-51.

El-Dein, A.K.A., M.M. Soliman and S.A. El-Aziz. 2013. Effect of dietary vitamin E supplementation on some productive, reproductive and immunological traits of Inshas chickens strain. Egypt. Poult. Sci. 33(4):939-955.

Faria, F.D.E, P.S. Rosa, B.S. Vieira, M. Macari and R.L. Furlan. 2005. Protein levels and environmental temperature effects on carcass characteristics, performance, and nitrogen excretion of broiler chickens from 7 to 21 days of age. Brazilian J. Poult. Sci. 7(4):247-253. 
Fisinin, V.I. and A.Sh. Kavtarashvili. 2015. Heat stress in poultry. I. Danger, related physiological changes and symptoms (review). Agri. Biol. 50(2):162-171.

Ghazanfari, S., H. Kermanshahi, M. Nassiri, A. Golian, A. Heravi Moussavi and A. Salehi. 2010. Effect of feed restriction and different energy and protein levels of the diet on growth performance and growth hormone in broiler chickens. J. Biol. Sci. 10(1):25-30

Hamidi, H. and J. Pourreza. 2009. Effects of zincmethionine and feed restriction on performance, immunocompetence and gut content osmolarity of broilers challenged with a mixed coccidial infection. J. Biol. Sci. 9(7):669-675.

Haq, Z., R. Jain, A. Mahajan, I. A. Ganai, N. Khan and S. Mudasir. 2018. Dietary supplementation of chromium yeast alone and in combination with antioxidants for designing broiler meat. J. Entomol. Zool. Stud. 6(1):766-770.

Haq, Z., R.K. Jain, N. Khan, M.Y. Dar, S. Ali, M. Gupta and T.K. Varun. 2016. Recent advances in role of chromium and its antioxidant combinations in poultry nutrition (A review). Vet. World. 9(12):1392-1399.

Hosseini-Mansoub, N., S. Chekani-Azar, A.A. Tehrani, A. Lotfi, M. K. Manesh. 2010. Influence of dietary vitamin $\mathrm{E}$ and zinc on performance, oxidative stability and some blood measures of broiler chickens reared under heat stress $\left(35^{\circ} \mathrm{C}\right)$. J. Agrobiol. 27(2):103-110

Khan, R.U., S. Naz and K. Dhama. 2014. Chromium: pharmacological applications in heat-stressed poultry. Int. J. Pharmacol. 10(4):213-217.

Khan, R.U., S. Naz, Z. Nikousefat, M. Selvaggi, V. Laudadio and V. Tufarelli. 2012. Effect of ascorbic acid in heat-stressed poultry. World's Poult. Sci. J. 68(3):477-490.

Khetani, T. L., T.T. Nkukwana, M. Chimonyo and V. Muchenje. 2009. Effect of quantitative feed restriction on broiler performance. Trop. Anim. Health Prod. 41:379-384.

Lara, L.J., M.H. Rostagno. 2013. Impact of Heat Stress on Poultry Production (A review). Animals. 3:356-369.

Lin, H., H.C. JIao, J. BUYSE and E. Decuypere. 2006. Strategies for preventing heat stress in poultry. World's Poult. Sci. J. 62:71-86

Mack, L.A., J.N. Felver-Gant, R.L. Dennis and
H.W. Cheng. 2013. Genetic variations alter production and behavioral responses following heat stress in 2 strains of laying hens. Poult. Sci. 92(2):285-294

Mench, J. A. 2002. Broiler breeders: feed restriction and welfare. World's Poult. Sci. J. 58(1):23-29.

Mohamed, A.S.A., A.R. Lozovskiy and A.M.A. Ali. 2019. Nutritional strategies to alleviate heat stress effects through feed restrictions and feed additives (vitamins and minerals) in broilers under summer conditions. J Anim Behav. Biometeorol. 7(3):123-131.

Naz, S., M. Idris, M.A. Khalique, Zia-UrRahman, I.A. Alhidary, M.M. Abdelrahman, R.U. Khan, N. Chand, U. Farooq and S. Ahmad. 2016. The activity and use of zinc in poultry diets. World's Poult. Sci. J. 72(1): 159-167.

Nielsen, B.L., M. Litherland and F. Nøddegaard. 2003. Effects of qualitative and quantitative feed restriction on the activity of broiler chickens. Appl. Anim. Behav. Sci. 83(4): 309-323.

Niu, Z.Y., F.Z. Liu, Q.L. Yan and W. C. Li. 2009. Effects of different levels of vitamin $\mathrm{E}$ on growth performance and immune responses of broilers under heat stress. Poult. Sci. 88(10): 2101-2107.

Novele, D.J., J.W. Ng'Ambi, D. Norris and C.A. Mbajiorgu. 2008. Effect of sex, level and period of feed restriction during the starter stage on productivity and carcass characteristics of Ross 308 broiler chickens in South Africa. int. J. Poult. Sci. 7(6):530537.

NRC (National Research Council). 1994. Nutrient requirements of poultry. $9^{\text {th }}$ revised edition. Washington, DC: National Academy Press.

Özkan, S., Ç. Takma, S. Yahav, B. Söğüt, L. Türkmut, H. Erturun and A. Cahaner. 2010. The effects of feed restriction and ambient temperature on growth and ascites mortality of broilers reared at high altitude. Poul. Sci. 89(5):974-985.

Pompeu, M.A., L.F.L. Cavalcanti and F.L.B. Toral. 2018. Effect of vitamin E supplementation on growth performance, meat quality, and immune response of male broiler chickens: A meta-analysis. Livest. Sci. 208:5-18.

Rincon, M.U. and S. Leeson. 2002. Quantitative and qualitative feed restriction on growth characteristics of male broiler chickens. 
Poult. Sci. 81(5):679-688.

Sahin, K. and O. Kucuk. 2003. Zinc supplementation alleviates heat stress in laying Japanese quail. J. Nutr. 133(9):28082811.

Sahin, N., A. Hayirli, C. Orhan, M. Tuzcu, J. R. Komorowski and K. Sahin. 2018. Effects of the supplemental chromium form on performance and metabolic profile in laying hens exposed to heat stress. Poult. Sci. 97(4): 1298-1305.

SAS Institute. 2003. SAS/STAT user's guide: Statistics, version 6, 4th ed., Vol. 2. Cary, NC: SAS Insitute.

Shabani, S., A. Seidavi, L. Asadpour and M. Corazzin. 2015. Effects of physical form of diet and intensity and duration of feed restriction on the growth performance, blood variables, microbial flora, immunity, and carcass and organ characteristics of broiler chickens. Livest. Sci. 180: 150-157.

Smith, P. and P.J. Gregory. 2013. Climate change and sustainable food production. Proc. Nutr. Soc. 72(1):21-28.

Tawfeek, S.S., M.A.H. Kamel and M.I.Y. Ibrahim. 2014. The Effect of Dietary Supplementation of Some Antioxidants on Performance, Oxidative Stress, and Blood Parameters in Broilers under Natural Summer Conditions. J. World's Poult. Res, 4(1):10-19.

Toghyani, M., M. Shivazad1, A.A. Gheisari and S.H. Zarkesh. 2006. Performance, carcass traits and hematological parameters of heatstressed broiler chicks in response to dietary levels of chromium picolinate. Int. J. Poult. Sci. 5(1):65-69.

Wang. X. J, J.H. Feng, M.H. Zhang, X. M. Li, D.D. Ma and S.S. Chang. 2018. Effects of high ambient temperature on the community structure and composition of ileal microbiome of broilers. Poult. Sci. 97(6): 2153-2158.

Xue, Bo., Jiao. Song, Longzhou. Liu, Jingxian. Luo, Guangming. Tian and Ye. Yang. 2017. Effect of epigallocatechin gallate on growth performance and antioxidant capacity in heat-stressed broilers. Arch. Anim. Nutr. 71(5):362-372.

Yang, X., J. Zhuang, K. Rao, X. Li, and R. Zhao. 2010. Effect of early feed restriction on hepatic lipid metabolism and expression of lipogenic genes in broiler chickens. Res. Vet. Sci. 89(3):438-444.

Zakaria, H.A., M.I. Jalal, H.H.I. AL-Titi and A.I. Souad. 2017. Effect of sources and levels of dietary zinc on the performance, carcass traits and blood parameters of broilers. Brazilian J. Poult. Sci. 19(3):519-526.

Zhan, X.A., M. Wang, H. Ren, R.Q. Zhao, J.X. Li and Z. L. Tan. 2007. Effect of early feed restriction on metabolic programming and compensatory growth in broiler chickens. Poult. Sci. 86(4):654-660.

Zhang, C., X.H. Zhao, L. Yang, X.Y. Chen, R.S. Jiang, Jin. S.H and Z.Y. Geng. 2017. Resveratrol alleviates heat stress-induced impairment of intestinal morphology, microflora, and barrier integrity in broilers. Poult. Sci. 96(12):4325-332.

Zhu, Y.W., W.X. Li, L. Lu, L.Y. Zhang, C. Ji. X. Lin, H.C. Liu, J. Odle and X.G. Luo. 2017. Impact of maternal heat stress in conjunction with dietary zinc supplementation on hatchability, embryonic development, and growth performance in offspring broilers. Poult. Sci. 96(7):23512359. 